\title{
REKALKULASI BEBAN LISTRIK KAPAL UNTUK PENENTUAN DAYA GENERATOR PADA MV. PRATIWI MENGGUNAKAN RULE BKI
}

\author{
Syifa Ath Thoriq ${ }^{1}$, Sri Pramono ${ }^{1 *}$, Chandra Yogatama ${ }^{1}$ \\ Program studi Teknik Permesinan Kapal, Fakultas Kemaritiman, Universitas IVET Semarang \\ Jl. Pawayatan Luhur IV/17, Bendan Dhuwur, Semarang. \\ "Email: sripramono8sep@gmail.com
}

\begin{abstract}
Abstrak
Regulasi mengenai kelistrikan kapal diatur oleh berbagai badan di dunia. Untuk Indonesia, salah satu badan yang mengatur mengenai kelistrikan kapal adalah BKI (Biro Klasifikasi Indonesia). Salah satu hal yang diatur oleh regulasi BKI adalah konfigurasi generator. Konfigurasi generator ini ditentukan berdasarkan beban kelistrikan kapal. Regulasi BKI secara periodik terus diperbarui untuk mencapai keandalan dan keselamatan pelayaran sesuai dengan masanya. Regulasi ini sangat bermanfaat dalam perancangan kapal-kapal baru. Namun, hal ini juga menimbulkan keraguan mengenai kapal-kapal terdahulu. Muncul pertanyaan apakah kapal tersebut sudah sesuai dan bagaimana menyesuaikan kapal tersebut dengan regulasi BKI sekarang. Penelitian yang dibahas oleh Jurnal Perancangan Kebutuhan Daya Listrik pada Kapal Perintis 2000 GT Dengan Electric Balance BKI sudah membahas hal tersebut. Sayangnya penelitian itu menggunakan regulasi yang sekarang sudah tidak digunakan. Dibutuhkan penelitian sejenis yang menggunakan regulasi yang baru. Penelitian ini membahas implementasi regulasi BKI tahun 2020 pada kapal MV. Pratiwi. Setelah dilakukan implementasi Rules For Electrical Instalation BKI tahun 2020 didapatkan kapasitas generator minimum yang dibutuhkan harus mampu melakukan suplai hingga $353 \mathrm{KW}$. Konfigurasi yang disarankan adalah 2 generator dengan daya berbeda dengan 1 generator memenuhi kebutuhan daya terlama yakni $229 \mathrm{KW}$ dan generator lainnya untuk memenuhi beban puncak $353 \mathrm{KW}$.
\end{abstract}

Kata kunci: Beban, BKI, Kapal, Listrik, Generator.

\section{PENDAHULUAN}

Biro Klasifikasi Indonesia merupakan sebuah badan yang secara periodik mengeluarkan regulasi untuk mengatur hal terkait bidang kemaritiman. Salah satu yang diatur regulasinya adalah mengenai kelistrikan kapal. Salah satu regulasi terbaru yang mengatur kelistrikan kapal diterbitkan pada tahun 2020 dengan judul Volume IV Rules For Electrical Instalation.

Penerbitan regulasi tersebut memunculkan keraguan mengenai kapal yang dibuat sebelum penerbitan sudah memenuhi regulasi tersebut atau belum. Terutama bila kapal tersebut masih bisa berlayar secara normal. Dibutuhkan penelitian tentang implementasi regulasi BKI sekarang terhadap kapal-kapal terdahulu untuk mendapat rekomendasi generator yang digunakan.

Penelitian yang disajikan pada Jurnal Perancangan Kebutuhan Daya Listrik pada Kapal Perintis 2000 GT Dengan Electric Balance BKI (Suyanto, Aris. 2017) telah membahas hal tersebut. Penelitian tersebut terfokus pada regulasi BKI tahun 2004 dan bukan regulasi yang baru atau digunakan sekarang yakni regulasi tahun 2020. Maka, dibutuhkan penelitian dengan regulasi yang baru atau digunakan sekarang terhadap kapal yang masih beroperasi.

Salah satu contoh kapal yang sudah beroperasi ketika regulasi tahun 2020 terbit adalah MV. Pratiwi. Penelitian ini membahas implementasi regulasi BKI pada 2020 volume IV Rules For Electrical Instalation terhadap beban kapal MV. Pratiwi sehingga didapatkan rekomendasi generator.

\section{LANDASAN TEORI \\ Daya dan Beban}

Daya adalah besaran laju hantaran energi listrik yang terjadi pada suatu rangkaian listrik, daya terbagi menjadi 3, yakni daya aktif, daya reaktif, dan daya semu. Beban dibagi menjadi 3, yakni beban resesif, beban induktif, dan beban kapasitif. (Margudani, A.R. 1991)

\section{Kondisi Operasional Kapal \\ Kondisi operasional kapal adalah: \\ 1. Berlayar: Kondisi ketika kapal lurus}


2. Manuver: kondisi ketika kapal berbelok

3. Bongkar Muat: kondisi ketika kapal bongkar muat muatan

4. Berlabuh: kondisi ketika kapal meninggalkan pelabuhan

\section{Biro Klasifikasi Indonesia}

BKI Vol. IV Tahun 2020 mensyaratkan bahwa sekurang-kurangnya 2 agregat yang terpisah dari mesin penggerak utama harus disediakan untuk pemberi daya listrik. Daya keluaran harus berukuran sedemikian sehingga keluaran generator masih tersisa dan cukup untuk menutup kebutuhan daya dalam pelayaran dilaut ketika salah satu agregat rusak ataupun diberhentikan, daya keluaran dari generator yang sekurang-kurangnya diperlukan untuk pelayanan selama pelayaran dilaut harus $15 \%$ lebih besar dari kebutuhan daya yang ditentukan dalam balan daya

Perhitungan kebutuhan daya dikapal menggunakan dari kondisi operasional kapal, tiap metode perhitungan mempunyai pandangan yang berbeda terhadap kondisi operasional kapal, yaitu:

1. Dua Kondisi : Kondisi Berlayar dan Berlabuh

2. Tiga Kondisi : Kondisi Berlayar, Berlabuh, dan Manuver

3. Empat Kondisi : Kondisi Berlayar, Manuver, Bongkar Muat, dan Berlabuh

4. Delapan Kondisi : Kondisi Berlayar, Manuver, Bongkar Muat, Berlabuh yang dibagi dalam kondisi siang dan malam

Load Factor yang disyaratkan oleh Biro Klasifikasi Indonesia adalah $85 \%$ kapasitas generator. Pada penerapannya ,nilai load factor yang digunakan biasanya berkisar antara 60\%85\% dan 60\%-90\%. Load Factor untuk peralatan listrik (tergantung dari jenis kapal, dan jarak pelayarannya)apabila tidak ada reifikasi ditentukan $50 \%$ ke atas.

Faktor kesamarataan harus ditetapkan dengan dimasukkan pertimbangan beban tertinggi yang diharapkan dapat terjadi pada waktu yang sama, jika penentuan yang tepat tidaklah mungkin, faktor kesamarataan yang digunakan tidak boleh lebih kecil dari 0.5.

Dalam kondisi berlayar minimal harus ada satu generator yang standby, Output daya harus berkapasitas $15 \%$ lebih besar dari total kebutuhan listrik di atas kapal ,hal itu bertujuan untuk mengantisipasi arus start pada motormotor yang membutuhkan suplai daya 3 fasa .

\section{Pratiwi}

Perlatan listrik pada MV. Pratiwi dengan daya listrik adalah :
a. Machinery Part
b. Hull Part
c. Electrical Part

\section{Hipotesis}

Analisis perhitungan daya kebutuhan listrik dikapal yang didapatkan dari perhitungan faktor-faktor yang menjadi tolak ukur perencanaan kebutuhan listrik kapal dapat ditarik pernyataan sementara sebagai berikut :

1) Dari perhitungan analisis beban daya kebutuhan listrik dikapal didapat dua jenis daya yaitu daya maksimum dan daya minimum yang menjadi poin untuk penentuan perencanaan kebutuhan listrik kapal

2) Daya maksimum digunakan sebagai Penentuan kapasitas daya generator yang dibutuhkan kapal untuk beroperasi,

3) Sedangkan daya minimum digunakan untuk menentukan konfigurasi dari sistem pembangkit listrik yang sesuai serta untuk menentukan kapan generator dioperasikan

\section{METODE}

Metode penelitian ini adalah kuantitatif komparatif. Peneliti akan menghitung daya di lapangan dan membandingkan hasil perhitungan dengan kenyataan.

Dalam penelitian ini, peneliti akan membandingkan hasil perhitungan menggunakan regulasi dengan kondisi suplai daya di kapal sesungguhnya.

\section{Metode Pengumpulan Data}

pengumpulan data dengan ini menggunakan beberapa cara sebagai berikut :

1) Metode Tinjauan Langsung (survei)

2) Interviu / wawancara

3) Referensi.

\section{Analisis Data}

Perhitungan load analisis untuk menentukan kebutuhan generator pada kapal MV. Pratiwi menggunakan Rule BKI (Biro Klasifikasi Indonesia), perhitungan load analysis berbeda-beda tergantung pada masing- 
masing kondisi dan jenis kapal, dari data load analysis di rekalkulasi kembali dan di analisa. Rekalkulasi Electrical Load Analysis ini dibuat untuk mengetahui beban listrik atau daya yang dibutuhkan pada peralatan di atas kapal terebut, dalam laporan ini berasal data Electrical Load minimum generator yaitu $115 \%$ didapat dari $100 \%$ daya kebutuhan listrik kapal ditambah $15 \%$ daya. Sehingga didapatkan hasil $115 \%$ dari $306.9439 \mathrm{KW}$ adalah $352.985485 \mathrm{KW}$, atau bisa dibulatkan menjadi $353 \mathrm{KW}$.

\begin{tabular}{|c|c|c|c|c|c|c|c|}
\hline \multicolumn{8}{|c|}{ Tabel 1.Hasil Perhitungan Electrical Load Kapal MV. Pratiwi } \\
\hline No & \multicolumn{3}{|c|}{ ITEM } & Berlayar & Manuver & Bongkar & Berlabuh \\
\hline \multirow{4}{*}{1} & \multirow{4}{*}{$\begin{array}{l}\text { MACHINERY } \\
\text { PART }\end{array}$} & \multirow{2}{*}{$\begin{array}{l}\text { Engine } \\
\text { Service }\end{array}$} & $\mathrm{CL}$ & 118.52 & 116.62 & 27.55 & 27.55 \\
\hline & & & IL & 9.05 & 9.05 & 1.16 & 1.16 \\
\hline & & \multirow{2}{*}{$\begin{array}{l}\text { General } \\
\text { Service }\end{array}$} & $\mathrm{CL}$ & 9.31 & 9.31 & 11.54 & 11.54 \\
\hline & & & IL & 28.82 & 26.71 & 26.71 & 26.71 \\
\hline \multirow[t]{2}{*}{2} & \multirow{2}{*}{\multicolumn{2}{|c|}{ HULL PART }} & $\mathrm{CL}$ & 45.84 & 44.68 & 202.2 & 91.4 \\
\hline & & & IL & 0.00 & 0.00 & 31.71 & 31.71 \\
\hline \multirow[t]{4}{*}{3} & \multirow{4}{*}{$\begin{array}{l}\text { ELECTRICAL } \\
\text { PART }\end{array}$} & \multirow{2}{*}{$\begin{array}{l}\text { Lightning \& } \\
\text { Stop Contact }\end{array}$} & $\mathrm{CL}$ & 22.66 & 22.66 & 22.66 & 22.66 \\
\hline & & & IL & 0.00 & 0.00 & 0.00 & 0.00 \\
\hline & & \multirow{2}{*}{$\begin{array}{l}\text { Navigation, } \\
\text { Communicat } \\
\text { ion \& Safety }\end{array}$} & $\mathrm{CL}$ & 6.127 & 6.127 & 1.227 & 1.227 \\
\hline & & & IL & 0.097 & 0.097 & 0.097 & 0.097 \\
\hline \multicolumn{4}{|c|}{ Total Contiunes Load } & 202.457 & 199.397 & 265.177 & 154.377 \\
\hline \multicolumn{4}{|c|}{ Total Intermitten Load } & 37.967 & $\mathbf{3 5 . 8 5 7}$ & 59.677 & 59.677 \\
\hline \multicolumn{4}{|c|}{ Diversity Factor 0.7 x d(intermetten) } & 26.5769 & 25.10 & 41.7739 & 41.7739 \\
\hline \multicolumn{4}{|c|}{ Jumlah Load (continue $+\mathrm{e}$ ) } & 229.0339 & 224.497 & & 196.1509 \\
\hline
\end{tabular}

Analysis kapal MV. Pratiwi yang menggunakan Rule BKI

\section{HASIL DAN PEMBAHASAN \\ Kapasitas Generator Minimum}

Perhitungan dilakukan pada berbagai jaringan kelistrikan kapal dan didapat hasil sesuai yang ditunjukkan oleh tabel 1. Dari aturan atau Rule yang telah ditetapkan oleh BKI. Ketika kapal Beroperasi maka load factor muatan generator tidak melebihi $85 \%$ atau $100 \%$ daya kebutuhan listrik dikapal tersebut hanya $85 \%$ dari kapasitas daya generator sehingga generator tidak mencapai daya kerja yang maksimum yang bertujuan untuk keselamatan berlayar. Jadi daya

\section{Simulasi Penggunaan Generator}

Dalam penentuan penggunaan jumlah generator Biro Klasifikasi Indonesia (BKI) mensyaratkan bahwa sekurang-kurangnya terdapat 2 agregat yang terpisah dari mesin penggerak utama harus disediakan untuk pembangkit daya listrik

\section{a. 2 generator daya sama}

minimum kapasitas generator yang dibutuhkan adalah $353 \mathrm{kw}$ dapat digunakan dengan 2 generator yang masing-masing memiliki daya $177 \mathrm{KW}$, 
namun jika menggunakan konfigurasi generator seperti ini maka pada saat kapal beroperasi kedua generator tersebut harus berfungsi bersamaan secara terus menerus menjadikan keselamatan generator tidak ada dan berisiko

\section{b. 2 generator daya berbeda}

penggunaan 2 generator dengan satu daya yang kecil yaitu generator 1 ( 120 kw) dan satu daya yang besar yaitu generator 2 ( $230 \mathrm{kw}$ ) pada konfigurasi ini memiliki keselamatan yang lebih baik dari pada konfigurasi yang pertama dikarenakan dapat menggunakan generator tidak harus secara bersamaan

\section{c. 3 generator 2 sama 1 beda}

Dari ke 2 konfigurasi jumlah generator yang sebelumnya konfigurasi ini adalah yang paling aman karena terdapat 3 generator yang dapat digunakan secara bergantian jadi generator tidak beroperasi maksimum secara terus menerus namun disisi lain tingkat efisiensi bahan bakar dan kebutuhan ruang dimensinya lebih besar

Dari hasil simulasi penggunaan jumlah generator, direkomendasikan menggunakan konfigurasi 2 generator dengan daya yang berbeda yaitu dengan daya Generator $1=250 \mathrm{kw}$ dan Generator $2=100 \mathrm{kw}$, Karena berdasarkan dari penggunaan daya yang paling lama digunakan atau beroperasi adalah saat berlayar dengan kebutuhan daya 229.0339 KW sehingga dapat menggunakan Generator 1 saja saat berlayar dan generator 2 dapat digunakan sebagai safety dan pada saat membutuhkan daya beban puncak kapal dalam beroperasi

\section{KESIMPULAN}

Penelitian ini mengambil kesimpulan sebagai berikut:

1) faktor yang perlu diperhatikan Dalam menentukan perencanaan kebutuhan listrik kapal adalah jenis fungsi kapal, rute pelayaran kapal, dan karakter pembebanan perlatan.

2) Perhitungan analisis daya ini didapat hasil daya maksimum sebagai penentuan kebutuhan daya generator dan daya minimum untuk menentukan konfigurasi dari system pembangkit listrik yang sesuai

3) Hasil Electrical Load yang telah dihitung didapatkan jumlah Daya Continues Load terbesar dalam kondisi Cargo Operation 265.177 KW dan hasil Daya Intermitten terbesar adalah dalam kondisi Bongkar Muat Dan Berlabuh yaitu $59.677 \mathrm{KW}$. Total load terbesar yaitu pada kondisi Bongkar Muat pada 306.9439 KW.

4) Dari Rule yang telah ditetapkan oleh BKI. Ketika kapal Beroperasi maka load factor muatan generator tidak melebihi $85 \%$ atau $100 \%$. Daya kebutuhan listrik dikapal tersebut hanya $85 \%$ dari kapasitas daya generator. maka daya Minimum Kapasitas generator adalah $115 \%$ dari Total load terbesar yakni $115 \%$ dari 306.9439 KW yaitu $352.985485 \mathrm{KW}$ atau $353 \mathrm{~kW}$

5) Rekomendasi yang disarankan adalah konfigurasi 2 generator dengan daya yang berbeda Karena berdasarkan penggunaan daya yang paling lama digunakan adalah saat berlayar dengan 229.0339 KW sehingga dapat menggunakan Generator 1 saja saat berlayar dan generator 2 dapat digunakan sebagai keselamatan dan pada saat membutuhkan daya beban puncak kapal dalam beroperasi

\section{DAFTAR PUSTAKA}

Biro Klasifikasi Indonesia, 2020, Rules For Electrical Instalation, volume IV , RCN No.1,

Margudani, A.R, 1991, Dasar-dasar teori rangkaian, Airlangga, Jakarta.

Tanalialayubi ,Slideshare.net,Perancangan kebutuhan listrik kapal pada kapal jenis oil Tanker; November 2015

Suyanto ,Aries, 2017, Jurnal Perancangan Kebutuhan Daya Listrik pada Kapal Perintis 2000 GT Dengan Electric Balance BKI, Undergraduated Thesis, UNIMUS, Semarang. 
Marshel, S., Dyonisius, 2014, Perancangan

Power Management System pada

Kapal Penumpang. Tugas Akhir.

Institut Teknologi Sepuluh November.

Surabaya 